\title{
IDM Module for the Management of Leaf Curl Disease in Chilli
}

\author{
Upesh Kumar $^{1 *}$ and Suresh Kumar ${ }^{2}$ \\ ${ }^{1}$ Krishi Vigyan Kendra, District - Patan, Gujarat, India \\ ${ }^{2}$ F-1, Krishi Farm, Samnapur tiraha, Amarkantak Road, Dindori (M.P.), India \\ *Corresponding author
}

\begin{abstract}
A B S T R A C T
Chilli is one of the most important commercial crops of India. It is grown almost

Keywords

Chilli, Leaf curl disease, Crop, India.

Article Info

Accepted:

21 August 2017

Available Online:

10 September 2017 throughout the country. India is a major producer, consumer and exporter of chilli in the world. Krishi Vigyan Kendra, Sehore (M.P.) are assess the Integrated Disease Management module (Resistant variety + seed treatment with Thiomethoxam 70 WS @ $3 \mathrm{gm} / \mathrm{kg}+$ Soil application of corbofuron@ $15 \mathrm{~kg} / \mathrm{ha}$ during transplanting of seedlings+ planting of maize as a barrier crop + roughing out of infected plants at initial stage of infection+ 2-3 spray of systemic insecticides before flowering) for the management of leaf curl disease in chilli during Kharif season from 2009-10 and 2010-11. Reduction of leaf curl disease incidence in demonstrated technology were ranges from $52.53 \%$ to $56.70 \%$ in 2009-10 and 2010-11, respectively over farmers practice resulted enhance the average productivity were ranges from $18.28 \%$ to $20.73 \%$.
\end{abstract}

\section{Introduction}

Chilli (Capsicum annuum L.) is an important spice crop grown for its fruits, which are used in green as well as ripe dried form for its pungency. Chilli belongs to the genus Capsicum family Solanaceae. Chilli has two important commercial qualities. If some varieties are famous for red colour because of the capsathin, others are known for biting pungency attributed by capsicin. The chilli is known for its flavor and pungency due to capsicum and having a medicinal value. It has tonic and carminative action. The enzyme isolated from chilli is used in the treatment of certain type of cancers. Green chilli contains a good amount of vitamin $\mathrm{C}$ and is also a good source of vitamin $\mathrm{A}$ and $\mathrm{B}$.
It contains small quantities of protein, fats, carbohydrates and minerals like phosphorus, iron and calcium.

The chilli leaf curl virus (CLCV) disease on chilli was first reported in Pakistan by Shih et al., (2003) and in India by Senanayake et al., (2006). Chilli crop suffers from a large number of viral, fungal, bacterial, nematode and phytoplasma diseases. Of the several diseases, viruses are known to cause different symptoms like mosaic, ring spot, curling, yellowing, etc., on chilli and these symptoms result in heavy losses. Leaf curl virus in chilli has also been reported in India (Muniyappa and Veeresh, 1984). Earlier some workers 
have conducted studies on viral diseases on chilli considering the destructive nature, the extent of yield losses due to leaf curl complex ranged from 25 to 80 per cent (Pandurange Gouda, 1979).

Leaf curl virus is more prevalent disease in most chilli growing areas in sehore district. Chilli leaf curl virus cause vein clearing on young leaves at early stage of infection, upward or downward curling of young and old leaves and plant stunted in most cases. Curling of fruit are could be seen in mature plants. Leaf curl virus is transmitted by White fly. Sugiura et al., (1975) reported that chilli leaf curl virus dose not persist throughout the life span of the vector. Field experiments of chilli leaf curl are caused by CLCV transmitted by White fly and curl induced by mite and thrips feeding injury (Johnpulle, 1939). Leaf curl disease caused by mite showing downward curling of leaves, partial suppression of lamina near the petiole end and shiny bronze colour on the lower surface of leaves. Leaf curl due to thrips resulted upward curling of leaves and interveinal buckling. Leaf crinkle or leaf curl complex was observed on chillies by Hussain (1932). The vein clearing and leaf malformation was reported by Fernando and Pieries (1967). Curling of leaf margin, reduction in leaf size, vein clearing were observed in India, Sri Lanka and USA (Puttarudraih, 1959).

Leaf curl disease of chilli was emerged as a serious problem in Jodhpur district, the major chilli growing area of Rajsthan state. During December, very high disease incidence up to $100 \%$ observed in farmer's fields in Narwa and Tinwari villages. The characteristic field symptoms were upward curling, puckering and reduced size of leaves. Severely affected plants were stunted and produced no fruit. The virus from Narwa village was transmitted by whitefly (Bemisia tabaci) of test plants, which produced vein clearing, curling and stunting symptoms (Senanayake et al., 2006). Tomato leaf curl Joydebpur virus symptoms on chilli were as mild yellowing, severe leaf curling, leaf destortion, stunting and blistering observed in the fields of Ludhiana, Punjab State, India (Shih et al., 2006)

The disease is characterised by puckering of leaf blade, and gradual reduction in the size. Diseased plants flower poorly with low fruit set. In case of leaf curl the disease is characterised by curling of the leaves, and thickening and swelling of veins. In advanced stages the whole plant appears bushy, with stunted growth and fewer flowers.

\section{Materials and Methods}

The present study was carried out by the Krishi Vigyan Kendra, Sehore (M.P.) during Kharif season from 2009-10 and 2010-11 in farmer's field of in adopted villages of Krishi Vigyan Kendra. The total number of farmers under this programme was 10. For the assessment of technology, one control plot was also kept where farmer's practice was carried out. Data were collected with the help of personal contact and observations on yield data was also recorded at the time of threshing. The yield of each experiment was recorded in a systematic manner and the yield of farmer's practices was also recorded at the same time.

The results of farmers practice were compared with the technology of IDM module for the management of leaf curl disease in chilli - "Resistant variety + seed treatment with Thiomethoxam 70 WS @ 3 gm/ kg + Soil application of corbofuron @ 15 $\mathrm{kg} / \mathrm{ha}$ during transplanting of seedlings+ planting of maize as a barrier crop + roughing out of infected plants at initial stage of infection+ 2-3 spray of systemic insecticides before flowering". 
The observations on number of plants infected with the leaf curl disease (CLCV) were recorded at 20 days interval till physiological maturity. The percentage of disease incidence was assessed by recording the number of plants showing disease symptoms out of total number of plants examined by using the formula mentioned below.

Number of diseased plants X 100 Per cent disease incidence $=$

Total number of plants examined

The yield data were collected from both the demonstration and farmer's practice and workout to calculate the technology gap; extension gap and the technology index as given below (Samui et al., 2000).

Technology gap $=$ Potential yielddemonstration yield

Extension gap $=$ Demonstration yield farmer's yield

(Potential yield-demonstration yield) X 100 Technology index =

Potential yield

\section{Results and Discussion}

Total 10 no of experiments were conducted at farmer's field in their farming situation. Table
1 revealed that the reduction of leaf curl disease incidence in demonstrated technology were ranges from $52.53 \%$ to $56.70 \%$ in 2009-10 and 2010-11, respectively over farmers practice. The average yield under demonstration fluctuated and ranged from $85.4 \mathrm{q} \mathrm{ha}^{-1}$ and $86.2 \mathrm{q} \mathrm{ha}^{-1}$ during the 2009-10 and 2010-11, respectively. The results clearly indicated that the yield of chilli could be increased by $18.28 \%$ to $20.73 \%$ over the yield obtained under farmer's practices of chilli cultivation due to adoption of IDM module for the management of leaf curl disease. Dixit and Singh (2003) were also found the similar type of findings.

The extension gap which ranged from $13.2 \mathrm{q}$ $\mathrm{ha}^{-1}$ to $14.8 \mathrm{q} \mathrm{ha}^{-1}$ during the period of study emphasized the need to educate the farmers through various means for adoption of Integrated Disease Management module for the management of leaf curl disease in chilli.

The technology gap was ranged from $23.8 \mathrm{q}$ $\mathrm{ha}^{-1}$ to $24.6 \mathrm{q} \mathrm{ha}^{-1}$, respectively in 2010-11 and 2009-10. The technology gap observed may be attributed to the dissimilarity in the trends adopted by farmers, day by day enhancing pest infestation as well as changing weather condition. Hence timely application of IDM technology for manage leaf curl disease in chilli incidence resulted minimize the technology gap for yield level of different situations.

Table.1 Disease incidence, productivity, extension gap, technology gap and technology index of chilli

\begin{tabular}{|c|c|c|c|c|c|c|c|c|c|}
\hline \multirow[t]{2}{*}{ Year } & \multicolumn{3}{|c|}{ Disease incidence (\%) } & \multicolumn{3}{|c|}{ Yield q/ha } & \multirow{2}{*}{$\begin{array}{l}\text { Extension } \\
\text { gap q/ha }\end{array}$} & \multirow{2}{*}{$\begin{array}{l}\text { Technology } \\
\text { gap q/ha }\end{array}$} & \multirow{2}{*}{$\begin{array}{l}\text { Technology } \\
\text { index } \%\end{array}$} \\
\hline & T1 & $\mathbf{T} 2$ & $\begin{array}{l}\% \\
\text { reduction }\end{array}$ & $\mathbf{T 1}$ & $\mathbf{T} 2$ & $\begin{array}{l}\% \\
\text { increase }\end{array}$ & & & \\
\hline $\begin{array}{c}2011- \\
12 \\
\end{array}$ & 20.6 & 9.8 & -52.43 & 72.2 & 85.4 & 18.28 & 13.2 & 24.6 & 22.36 \\
\hline $\begin{array}{c}2015- \\
16 \\
\end{array}$ & 19.4 & 8.4 & -56.70 & 71.4 & 86.2 & 20.73 & 14.8 & 23.8 & 21.64 \\
\hline Mean & 20 & 9.1 & -54.56 & 71.8 & 85.8 & 19.51 & 14 & 24.2 & 22.0 \\
\hline
\end{tabular}


Table.2 Economics analysis

\begin{tabular}{|c|c|c|c|c|c|c|c|c|c|c|}
\hline \multirow[t]{3}{*}{ Year } & \multicolumn{3}{|c|}{ Demonstration } & \multicolumn{3}{|c|}{ Farmer practices } & \multirow{3}{*}{\begin{tabular}{|l|} 
Additional \\
cost of \\
cultivation \\
Rs ha $^{-1}$
\end{tabular}} & \multirow{3}{*}{\begin{tabular}{|l|} 
Additional \\
net return \\
Rs ha $^{-1}$
\end{tabular}} & \multirow{2}{*}{\multicolumn{2}{|c|}{$\begin{array}{l}\text { Incremental } \\
\text { benefit cost } \\
\text { ratio }\end{array}$}} \\
\hline & \multirow{2}{*}{$\begin{array}{l}\text { Cost of } \\
\text { cultivatio } \\
\text { n Rs ha }^{-1}\end{array}$} & \multirow{2}{*}{$\begin{array}{l}\text { Gross } \\
\text { returns } \\
\text { Rs ha }^{-1}\end{array}$} & \multirow{2}{*}{$\begin{array}{l}\text { Net } \\
\text { return } \\
\text { Rs ha }^{-1}\end{array}$} & \multirow{2}{*}{$\begin{array}{l}\text { Cost of } \\
\text { cultivati } \\
\text { on Rs } \\
\text { ha }^{-1}\end{array}$} & \multirow{2}{*}{$\begin{array}{l}\text { Gross } \\
\text { returns } \\
\text { Rs ha }^{-1}\end{array}$} & \multirow{2}{*}{$\begin{array}{l}\text { Net } \\
\text { return } \\
\text { Rs ha }^{-1}\end{array}$} & & & & \\
\hline & & & & & & & & & T1 & $\mathbf{T} 2$ \\
\hline 2011-12 & 50700 & $\begin{array}{c}12810 \\
0\end{array}$ & 77400 & 48200 & $\begin{array}{c}10830 \\
0\end{array}$ & 60100 & 2500 & 17300 & 2.25 & 2.53 \\
\hline $2015-16$ & 50900 & $\begin{array}{c}15516 \\
0\end{array}$ & $\begin{array}{c}10426 \\
0\end{array}$ & 48700 & $\begin{array}{c}10710 \\
0\end{array}$ & 58400 & 2200 & 45860 & 2.20 & 3.05 \\
\hline Mean & 50800 & $\begin{array}{c}14163 \\
0\end{array}$ & 90830 & 48450 & $\begin{array}{c}10770 \\
0\end{array}$ & 59250 & 2350 & 31580 & 2.22 & 2.79 \\
\hline
\end{tabular}

T1- Farmers practice, T2 - Recommended practice

The technology index shows that the feasibility of the evolved technology at the farmer's fields. The lower value of technology index more feasibility of the technology. As such, reduction of technology index from $22.36 \%$ in 2009-10 and $21.64 \%$ in 2010-11. The variation in yield from location to location can be accounted for varying climatic condition, prevailing microclimatic and variation in agricultural practices followed by farmers resulted very in yellow mosaic disease incidence. More or less similar findings are found by Sagar and Chandra, 2004.

Table 2 showed that the cost of production under assessment was Rs. 15200 to Rs. 15500 per hectare in 2011-12 and 2015-16, respectively while the cost of farmer practice (FP) Rs.50700 to $50900 \mathrm{ha}^{-1}$ in 2009-10 and 2010-11, respectively. The dat were also revealed that the average net return from technology Rs $90830 \mathrm{ha}^{-1}$, while average net return from farmers practice was Rs. 59250 $\mathrm{ha}^{-1}$. It means the net return from assessed technology was higher than farmer's practices. Similar finding are found by Kumar and Kumar, 2012. The additional cost Rs.2500 to Rs.2200 gave additional net return, it was ranged Rs. 17300 to Rs. 45860 per hectare in 2009-10 and 2010-11, respectively. The increased benefit: cost ratio was also calculated, it was ranged from 1:2.53 to $1: 3.05$ in demonstration and $1: 2.25$ to $1: 2.20$ in farmers practice, respectively in 2009-10 and 2010-11.

Thus, it was clearly showed that the IDM modules for the management of leaf curl disease in chilli are more effective technology over farmers practice. In this technology ecofriendly and timely manage the yellow mosaic disease in green gram resulted enhance the net profit. The results indicated that the assessed technology has given a good impact among the farming community of Sehore district as they were motivated for future adoption of the technology.

\section{References}

Chattopadhyay, B., Singh AK, Yadav T, Fauquet CM, Sarin NB, Chakraborty $S, 2008$. Infectivity of the cloned components of a begomovirus: DNA- $\beta$ complex causing chilli leaf curl disease in India. Archives of Virology 153, 5339.

Dixit, S. N., and Singh, S. P. 2003. Evaluation of improved techniques on tomato and onion under frontline demonstration. Bharitiya Krishi anusandhan patrika. 18 (1 \& 2):61-64

Hussan, M.A., 1932, Leaf curl in cotton and 
other plants. Nature (London), 103: 312. Johnpulle, A.L., 1939. Leaf curl experiments. Tropical Agric. XCII: 28-30.

Muniyappa, V. and Veeresh, G. K., 1984, Plant virus diseases transmitted by whiteflies in Karnataka. Proc. of Indian Acd. Sci., (Anim. Sci.) 93: 397-406

Pandurange Gowda, K. T., 1979. Studies on chilli (Capsicum annuum Limn.) mosaic viruses occurring in some parts of Kolar district. M. Sc. (Agri.) Thesis, Univ. Agric. Sci., Bangalore, Karnataka (India).

Puttarudraiah, M., 1959. Short review on the chilli leaf curl complex and spray programme for its control. Mysore Agric. J., 34 (2): 93-95.

Sagar, R.L., and Ganesh Chandra 2004. Frontline demonstration on seasame in West Bengal. Agricultural Extension Review 16(2):7-10

Samui, S.K., Moitra, S., Ray, D.K., Mandal, A.K. and Saha, D. 2000. Evaluation of frontline demonstration on groundnut. Journal of the Indian Society Costal
Agricultural Research 18(2):180-183. Senanayake, D. M. J. B., Mandal, B., Loha, S. and Verma, A., 2006. First report of Chilli leaf curl virus affecting chilli in India. New Disease Rep. 13 [http://www.bspp.org.uk/ndr/July200635. asp].

Shih, S. L., Tsai, W. S., Green, S. K. and Singh, D., 2006. First Rep. Tomato Leaf Curl Joydebpur Virus Infecting Chilli in India,*skg@avrdc.org Accepted for publication 08/09/2006.

Shih, S. L., Tsai, W. S., Green, S. K., Khalid, S., Ahmed, I. and Rezaian, M. A., 2003. Molecular Characterization of tomato and chilli leaf curl begomoviruses from Pakistan. Plant Disease, 87: 200.

Shih, S.L., Tsai WS, Green SK, Singh D, 2007. First report of Tomato leaf curl Joydebpur virus infecting chilli in India. Plant Pathology 56, 341.

Sugiura Miyoji, Bandaranayake, C.M. and Hemachandra G.H. (1975). Chilli virus disease in Sri Lanka. Tech; Bull. TARC. Japan. No-8.

\section{How to cite this article:}

Upesh Kumar and Suresh Kumar. 2017. IDM Module for the Management of Leaf Curl Disease in Chilli. Int.J.Curr.Microbiol.App.Sci. 6(9): 2087-2091. doi: https://doi.org/10.20546/ijcmas.2017.609.256 